\title{
ANALYSING SOVEREIGN CREDIT DEFAULT SWAPS OF BALTIC COUNTRIES
}

\author{
Arvydas KREGZDE ${ }^{1}$, Gediminas MURAUSKAS ${ }^{2}$ \\ ${ }^{1}$ Department of Differential Equations and Numerical Analysis, Faculty of Mathematics and Informatics, \\ Vilnius University, Naugarduko g. 24, LT-03225 Vilnius, Lithuania \\ ${ }^{2}$ Department of Econometric Analysis, Faculty of Mathematics and Informatics, Vilnius University, \\ Naugarduko g. 24, LT-03225 Vilnius, Lithuania \\ E-mails: ${ }^{1}$ arvydas.kregzde@mif.vu.lt (corresponding author); ${ }^{2}$ gediminas.murauskas@mif.vu.lt
}

Received 07 November 2014; accepted 10 March 2015

\begin{abstract}
The paper analyses development of the Baltic sovereign CDS market. The level of commonalities and differences in credit risk of the Baltic countries with regard to CDS spreads is investigated. We apply principal component analysis, regression analysis, correlation analysis methods and Granger causality test. Driving forces for changes of CDS spreads in the individual country are established. We discover that the main impact of CDS spread changes arrives from external sources. Our study reveals interdependence between CDS spreads of the Baltic countries and analyses a contagion effect of the change of CDS spreads.
\end{abstract}

Keywords: CDS, spread, credit, Baltic, risk, equity.

JEL Classification: G00, G01, G14.

\section{BALTIJOS ŠALIŲ KREDITO APSIKEITIMO SANDORIŲ ANALIZE்}

\author{
Arvydas KREGŽDE் $\dot{1}^{1}$, Gediminas MURAUSKAS ${ }^{2}$ \\ ${ }^{1}$ Vilniaus universitetas, Matematikos ir informatikos fakultetas, Diferencialiniu lygčiu ir skaičiavimo \\ matematikos katedra, Naugarduko g. 24, LT-03225 Vilnius, Lietuva \\ ${ }^{2}$ Vilniaus universitetas, Matematikos ir informatikos fakultetas, Ekonometrines analizés katedra, \\ Naugarduko g. 24, LT-03225 Vilnius, Lietuva \\ El.paštas: ${ }^{1}$ arvydas.kregzde@mif.vu.lt; ${ }^{2}$ gediminas.murauskas@mif.vu.lt
}

Iteikta 2014-11-07; priimta 2015-03-10

\begin{abstract}
Santrauka. Straipsnyje nagrinèjamos Baltijos šalių kredito apsikeitimo sandorių (KAS) rinkos. Analizuojami Baltijos šalių kredito rizikų, išreikštų KAS maržomis, panašumai ir skirtumai. Naudota principinių komponenčių analizė, regresinė ir koreliacinė analizè bei Grangerio priežastingumo testas. Nustatyti pagrindiniai veiksniai, darantys įtaką konkrečios šalies KAS pokyčiui. Nustatyta, kad išoriniai veiksniai yra pagrindiniai, lemiantys KAS pokytị. Atlikus tyrimą atskleistas ryšys tarp Baltijos šalių KAS maržų ir analizuojamas užkrato efektas, lemiantis KAS maržų pokyčius.
\end{abstract}

Reikšminiai žodžiai: kredito apsikeitimo sandoriai, marža, Baltijos šalys, rizika, akcijos.

Copyright $\odot 2015$ The Authors. Published by VGTU Press.

This is an open-access article distributed under the terms of the Creative Commons Attribution-NonCommercial 4.0 (CC BY-NC 4.0) license, which permits unrestricted use, distribution, and reproduction in any medium, provided the original author and source are credited. The material cannot be used for commercial purposes.

To link to this article: http://dx.doi.org/10.3846/btp.2015.551 


\section{Introduction}

The Baltic countries - Estonia, Latvia and Lithuania declared their independence in 1990. After collapse of the Soviet Union in 1991 the Baltic countries were recognised as sovereign by the broad international community. With a very similar starting point, the countries chose an independent way of development. Following a hangover from a purely administrational system of political and economic fundamentals, the countries took a way to a democratic political system based on market economy principles. Market economy creates new challenges, and management of the countries' risk is one of them.

A natural way of development of the Baltic countries has been tightening links with Western countries. Joining the European Union (EU) in 2004 was a new step of the Baltic countries to strengthening ties with Western countries and Nordic countries in particular. Introduction of the euro was the next step towards integration. Entering the eurozone was not unified. Latvia joined the eurozone in 2014 following Estonia which became the eurozone member in 2011. Lithuania is going to introduce the euro in 2015.

Despite a common recent history of the Baltic countries they have several differences. Fiscal policy and development of the stock of sovereign debt are very different in these countries. Historically, Estonia follows consolidated fiscal policy and consequently the sovereign debt of the country is the lowest in the $\mathrm{EU}^{1}$, whereas Latvia and Lithuania run a budget deficit. The budget deficit of Latvia and Lithuania reached 9.8 and 9.4 percent of the GDP in 2009 (European Commission 2014).

The world financial crisis of 2008 seriously shocked economies of the Baltic countries. These countries were the first in the EU, affected by the global credit crises. After continuous fast growth of economy the real GDP growth dropped by 14.1 percent for Estonia, 14.7 percent for Lithuania and 17.7 percent for Latvia in 2009, according to Eurostat 2014. The credit crush followed by a dramatic drop of GDP caused problems in the financial sector of the Baltic countries. In 2008 Parex bank was nationalised in Latvia. Two banks in Lithuania were closed down in 2011 and 2013.

Since the bankruptcy of Lehman Brothers, the credit risk of sovereigns has attracted particular attention. Before this event, credit market had been focused on corporate credit risk. The sovereign debt of the developed countries had been treated as risk free. The default risk of emerging markets was treated as very low. Starting from September 2008, the credit risk of the sovereigns was reassessed fundamentally. The credit risk of the countries of the EU was revised by the market on the largest scale. Even stable Nordic countries having a triple A ratings faced a revision of their credit risk.

1 According to European Commission (2014), Estonian sovereign debt was $10 \%$, Latvian $38.1 \%$ and Lithuanian $39.4 \%$ of the GDP in 2013.
The Credit Default Swap (CDS) of Sweden and Denmark reached 150 basis points (bps) in the beginning of 2009. The CDS spreads of the eurozone country - Finland - jumped to $80 \mathrm{bps}$. The credit risk of the Baltic countries increased at incredible scale. The Latvian CDS spreads reached 1050 bps and Lithuanian CDS jumped to 850 bps.

The aim of the article is to analyse sovereign CDS market of the Baltic countries from September 2008 to December 2013. The analysis of CDS spreads allows to some extent to study the credit risk of the countries. We investigate the level of commonalities and differences in credit risk of the Baltic countries in terms of CDS spreads. Our study reveals interdependence between CDS spreads of the Baltic countries and analyses a contagion effect of the change of CDS spreads. Driving forces for changes of CDS spreads are established. We applied principal component analysis, regression analysis, correlation analysis and Granger causality test methods.

The rest of the paper is structured as follows. Section 2 presents literature overview focusing on CDS as an indicator of credit risk. Section 3 discusses developments in the sovereign CDS market of the Baltic countries. Section 4 reveals the drivers of the CDS spreads of the Baltic countries. Section 5 analyses transmission of CDS spreads between the Baltic countries by using VAR together with Granger causality test. Section 6 presents a conclusion of the paper.

\section{Sovereign CDS spread as credit risk measure of the country}

Increase of the sovereign debt enhanced importance of the interest rate paid on the debt. Volatility of the market stresses a need to use a market-based measure of the borrowing cost. A common measure of the country's borrowing cost in an international market is a sovereign bond yield spread which is defined as a difference between the yield of the country's debt securities and the yield of the bonds of AAA rated sovereign. Currently the interest swap rate is used as an indicator of a risk free rate substituting the yield of high quality securities in defining a bond yield spread (see Beber et al. 2009). The sovereign bond yield spread is one of the measures of credit risk of the country.

CDS spread is an alternative measure of the sovereign credit risk. According to BIS (2012), the total outstanding notional amount of sovereign CDS ant the end of June 2013 was 3.4 trillion of USD dollars, which approximately is equal to $6 \%$ of sovereign debt. As a measure of credit risk, CDS spreads imply a probability of default of the sovereign combined with a recovery ratio in case of a default. One of the advantages of CDS spreads to bond yield spreads is that they explicitly express risk and there is no influence from a risk free yield curve which can be built using some models (Ericsson et al. 2009). Being a market indicator, CDS spreads incorporate 
some market "noise" which is not directly related to credit risk. It consists of the liquidity of the market, positions of traders and similar factors. Badaoui et al. (2013) argue that liquidity risk can have a substantial impact on the level of CDS spreads. Despite it, CDS spreads serve as an appropriate measure of credit risk.

Hull et al. (2004) analysed the relationship between CDS and credit rating announcements. They found that reviews for downgrade of the ratings contain significant information for CDS spreads, but a negative outlook of the rating does not. They established that credit spread changes and credit spread levels provide helpful information for estimation of a probability of negative credit rating changes. Remolona et al. (2008) decomposed CDS spread to default risk and risk-premium. The default risk is a function of Standard and Poor's and Moody's rating announcements. Jacobs et al. (2010) investigated the relationship between CDS spreads and credit ratings in order to explain how market participants perceive and price credit risk. They modelled credit default spreads and a variation between CDS spreads and credit ratings. Their empirical results indicated that after controlling for market returns, market volatility and interest rates, CDS spreads increase with a subordination of the credit quality of the reference entity. Wang and Yao (2014) investigated the strategies for international bonds and sovereign CDS trading.

The fact that credit risk can be measured by CDS spreads and yield spreads implied an interest of analysing these two variables together. A number of papers were devoted to analysis of the leading role of two variables: CDS spreads and bond yields of the same entity. As indicated by Blanco et al. (2005) and Zhu (2006), the CDS market surpasses the bond market in price discovery for corporate entities. Forte et al. (2009) applied VECM to find out the leading indicator among three variables: stock price volatility, bond spreads and CDS spreads. They established that stocks exceeded CDS and bonds. Their modelling shows that CDS play a leading role with respect to bonds. Norden, Weber (2009) proved that the CDS market contributes more to price discovery than the bond market and this effect is stronger for the US than for European firms.

There is a number of papers (IMF 2013; Fontana, Scheicher 2010) describing co-movement of sovereign CDS and bond spreads. It is commonly agreed by the authors that co-integration relationship of the variables holds reasonably well. IMF (2013) performed a comprehensive lead-lag analysis of CDS and bond spreads and made a conclusion that both of the indicators can be leading depending on the market conditions. Leadership of CDS spreads against bond spreads is different for advanced and developing economies. According to IMF (2013), CDS prices moved faster in advanced economies during the crisis period. Gyntelberg et al. (2013) analysed the co-movement of CDS and bonds spreads of the euro area countries during intraday trading.
They found that the CDS market dominated over the bond market in terms of price discovery in the vast majority of cases they examined. A lead-lag analysis for various euro area countries was carried out by many authors. The French CDS analysis was presented by Coudert, Gex (2010), the Italian case was described by Carboni (2011).

CDS spreads of different countries move together in the same direction. By using a principal component (PC) analysis, Longstaff et al. (2011) established a high level of commonality in sovereign credit spreads for a number of countries. He claimed that sovereign credit risk appeared to be much more linked to global factors than local equity returns were. The role of contagion for sovereign risk of 31 countries was analysed by Beirne and Fratzscher (2013). The authors found that the market pricing of sovereign risk may not have been fully reflecting fundamentals prior to the crisis. Alter and Beyer (2013) quantified spillovers between sovereign credit markets and banks in the euro area. Gorea and Radev (2014) examined the determinants of joint default risk of euro area countries during 2007-2011. They found that financial linkages are an active contagion transmission channel only in the case of the troubled periphery of the euro area economies. Ang and Longstaff (2013) found that both U.S and eurozone systemic sovereign risk was strongly related to financial market returns and systemic sovereign risk had its roots in financial markets rather than in macroeconomic fundamentals. Kallestrup et al. (2012) revealed that cross-border financial linkages were priced in CDS markets. They stated that implicit and explicit guarantees extended to a country's banking system in turn affected the CDS premium of the sovereign.

There is a number of papers analysing a contagion effect of the risk of the Central and East European countries (CEE) expressed in terms of CDS. Komarkova et al. (2013) demonstrated that credit risk was transmitted to the Czech Republic via a spillover cross-country effect. The transmission of negative shocks to the Czech Republic has already been analysed by Claeys and Vašíček (2012). By using a method based on a VAR model and bond spread data, they concluded that up to $44 \%$ of the dynamics of the Czech credit premiums could be explained by the dynamics of foreign premiums. Chobanov et al. (2013) analysed the relationship of CDS and money markets of the CEE countries. The authors found that the link became weaker and less pronounced for the inflation targeting countries. Kliber (2011) studied interaction between volatilities of the Central European CDS prices. The author analysed the impact of the Greek crisis and the economic situation in Hungary to CDS spreads of the Central European countries. The author did not find any direct impact of the increasing risk of Hungary on the CDS levels of other countries.

During the sovereign debt crisis, authorities of the EU followed developments in the sovereign CDS market 
very closely. In order to limit a possibility of speculative use of CDS, the EU regulation on "Short Selling and Certain Aspects of Credit Default Swaps" went into effect on 1 November 2012 (see European Commission 2010). The document seeks to reduce uncovered sovereign CDS trading in order to avoid the risk of increasing spread spirals for sovereign debt. In fact, the document limits short selling of uncovered debt instruments and CDS protection buying. Despite the restrictions, CDS play a crucial role in the European financial market.

\section{CDS market of the Baltic countries}

Lithuania entered an international capital market in 1995. The first Eurobond of Latvia was issued in 1999. The debt of Latvia and Lithuania has increased over time and investors had been willing to hedge their credit exposures. CDS is a

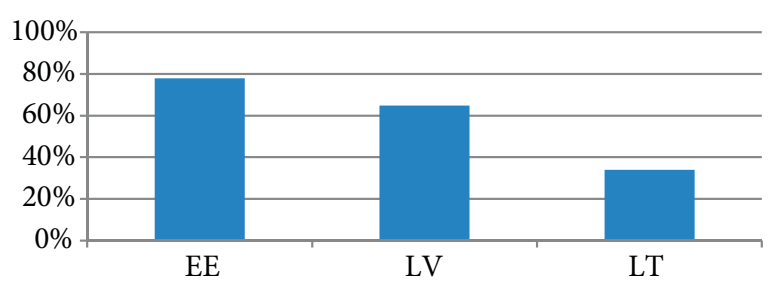

Fig. 1. The ratio of outstanding notional amount of CDS to sovereign debt on 31 December 2013 in percent (source: DTCC 2014, European Commission 2014) flexible market instrument to do it. Estonia has not issued any Eurobonds at all. Despite a very low debt of Estonia, the CDS market exists in Estonia. It shows that CDS are used not only for direct hedging of the reference entity exposure. The outstanding notional amounts of Estonian, Latvian and Lithuanian CDS were 1.9, 7.9 and 6.1 billion respectively in USD on 7 March 2014. The ratio of the outstanding notional amount of CDS to sovereign debt at the end of 2013 is presented in the Figure 1. It is worth to notice that according to BIS the ratio of the outstanding notional amount of CDS to the sovereign debt worldwide was equal to $6 \%$ in June 2013.

A low sovereign debt of Estonia implies that the ratio of the outstanding notional amount of CDS is fairly high. It is worth to notice that the outstanding notional amount of CDS has decreased for all the countries by $33 \%$ on the average from 9 March 2013 to 7 March 2014.

Volatility of liquidity of the CDS of the Baltic countries has been stable over time. Figure 2 presents a weekly average of a number of trades during half year periods from 3 September 2010 to 28 February 2014. Figure 3 plots a weekly average of traded amounts in million USD during half year periods from 3 September 2010 to 28 February 2014.

Our analysis of CDS focusses on 5-year CDS spreads as the most liquid part of the market. The 5-year CDS spreads of the Baltic countries from October 2008 to March 2014 are presented in Figure 4. Descriptive statistics of monthly

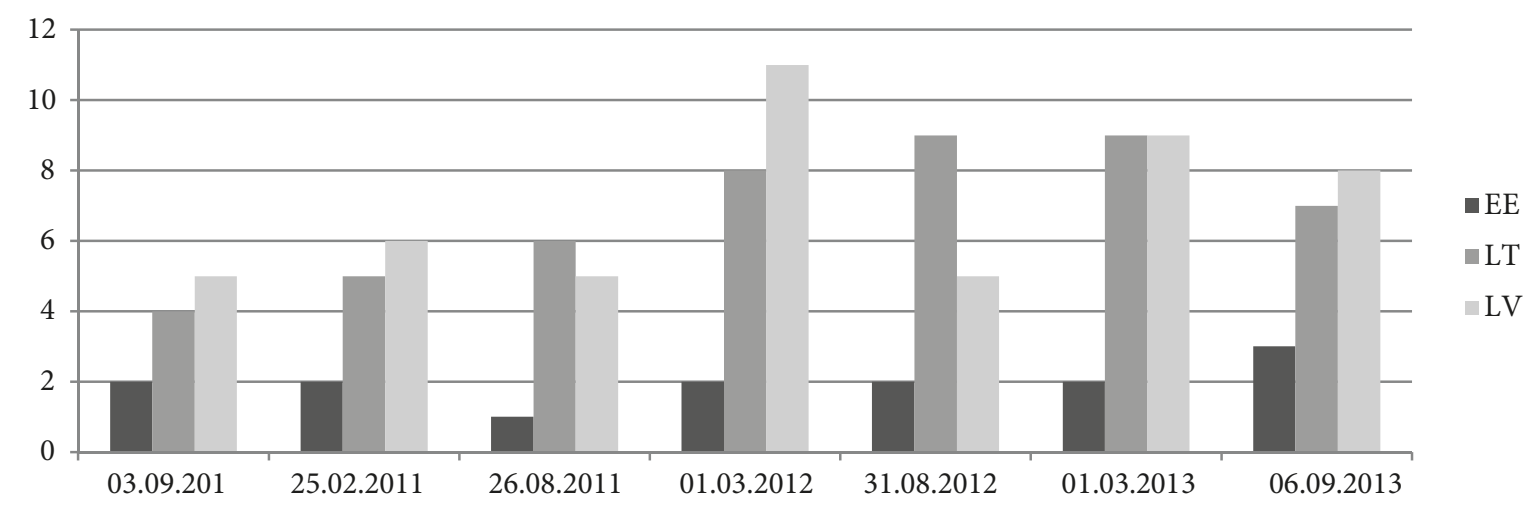

Fig. 2. Weekly average of number of trades during half year periods (source: DTCC 2014)

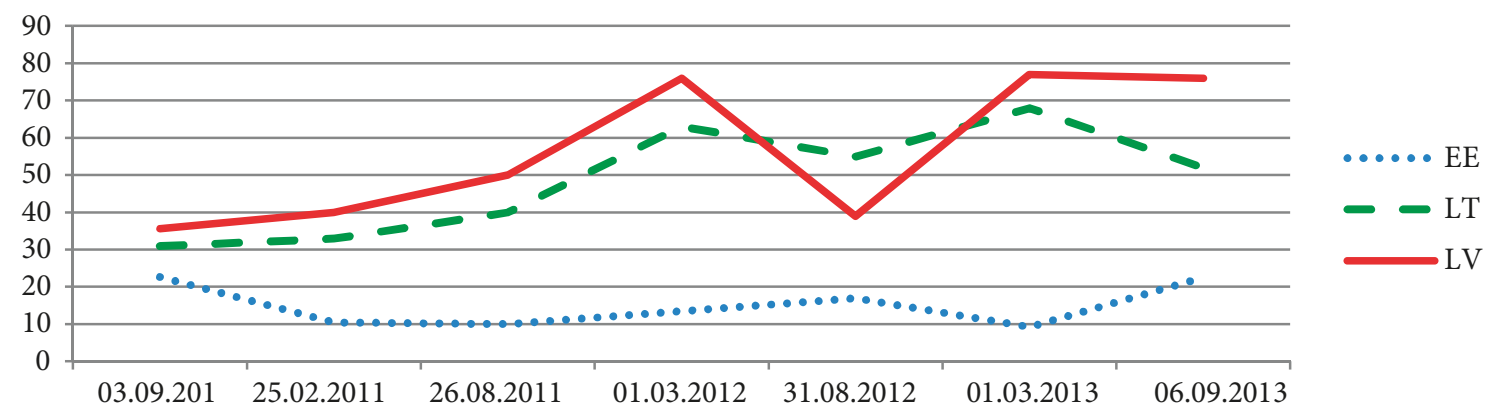

Fig. 3. Weekly average of traded amounts in million USD (source: DTCC 2014) 


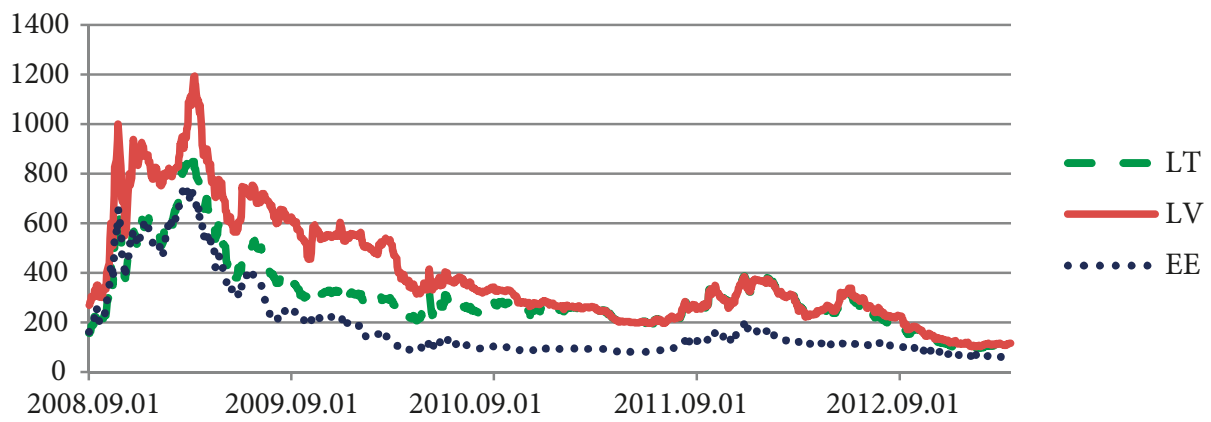

Fig. 4. CDS spreads of the Baltic countries in bps from September 2008 to December 2013 (source: Bloomberg)

changes of CDS spreads of the Baltic countries together with the Nordic countries are presented in Table 1. The highest level of CDS spreads and the highest standard deviation of the differences of CDS spreads are observed for Latvia. Consequently, the magnitude of volatility of credit risk of Latvia was the highest among the Baltic countries.

CDS spreads for the individual CEE countries have been analysed by a number of authors. Some researchers carried out a lead-lag analysis of CDS spreads and bond yields spreads. Varga (2009) studied development of CDS-bond basis spread in Hungary from February 2005 to June 2008, in order to compare the results of the Hungarian CDS market analysis in an international context ${ }^{2}$ covering the Baltic countries. He concluded that there was no clear leader in this market. Noteworthy, Varga analysed the markets before the crisis. A lead-lag analysis for CDS of the Czech Republic was performed by Komarkova et al. (2013). They found that the movements in the Czech sovereign CDS market preceded movements in the sovereign yield spread during the global crisis. A lead-lag analysis of the Lithuanian CDS and bond market during and after the crisis was investigated by Kregzde and Murauskas (2014).

Investigation of a pairwise relationship between monthly CDS spread changes ${ }^{3}$ of the countries under consideration was the first step in our analysis of credit risk sources of the Baltic countries. Correlation coefficients between monthly changes of CDS spreads from September 2008 to December 2013 are presented in Table 2a. We see from Table 2a that the correlation between CDS spreads changes is very high. We established that pairwise correlation coefficients were greater than 0.836 . The average correlation across the countries was equal to 0.880 . The greatest correlation was observed between CDS spread changes of Latvia and Lithuania which was equal to 0.935 . The phenomena

2 Varga (2009) analysed Brazil, Bulgaria, the Czech Republic, the Republic of South Africa, Estonia, Croatia, Poland, Latvia, Lithuania, Russia, Romania and the Slovak Republic.

3 In our analysis we focus on CDS spread changes rather than on CDS spreads, because CDS spread changes of the Baltic countries were stationary during the period analysed. can be explained by greater links of Estonia to the countries of the euro area.

Table 1. Descriptive statistics for monthly changes of CDS spreads from October 2008 to December 2013 for the Baltic and Nordic Countries

\begin{tabular}{|c|c|c|c|c|c|}
\hline & Mean & Std. Dev. & Sum & Minimum & Maximum \\
\hline LT & -1.62 & 61.73 & -102.35 & -166.00 & 237.50 \\
\hline LV & -3.40 & 83.78 & -214.15 & -213.33 & 377.50 \\
\hline EE & -2.71 & 50.56 & -170.50 & -169.00 & 242.50 \\
\hline DK & 0.10 & 17.68 & 6.25 & -48.34 & 57.25 \\
\hline FI & 0.09 & 10.04 & 5.92 & -30.28 & 26.31 \\
\hline SE & 0.01 & 12.78 & 0.67 & -34.32 & 45.73 \\
\hline
\end{tabular}

Table 2. Correlation coefficients between monthly changes of CDS spreads from October 2008 to December 2013

Table 2a. 10-2008 - 12-2013

\begin{tabular}{|c|c|c|c|}
\hline & EE & LT & LV \\
\hline EE & 1.000 & 0.870 & 0.836 \\
\hline LT & 0.870 & 1.000 & 0.935 \\
\hline LV & 0.836 & 0.935 & 1.000 \\
\hline
\end{tabular}

Table 2b. 10-2008 - 07-2010

\begin{tabular}{|c|c|c|c|}
\hline & EE & LT & LV \\
\hline EE & 1.000 & 0.903 & 0.847 \\
\hline LT & 0.903 & 1.000 & 0.896 \\
\hline LV & 0.847 & 0.937 & 1.000 \\
\hline
\end{tabular}

Table 2c. 07-2010 - 12-2013

\begin{tabular}{|c|c|c|c|}
\hline & EE & LT & LV \\
\hline EE & 1.000 & 0.816 & 0.799 \\
\hline LT & 0.816 & 1.000 & 0.965 \\
\hline LV & 0.799 & 0.965 & 1.000 \\
\hline
\end{tabular}

Note: All coefficients are significant at 1 percent level. 
Correlation between monthly changes of the sovereign CDS spreads was analysed by Longstaff et al. (2011). They found that the correlation between Chile and Mexico was 0.87 , the correlation between Korea and Malaysia was 0.82 and the correlation between Romania and Croatia was 0.91 . The average pairwise correlation observed throughout the countries ${ }^{4}$ was 0.62 . Authors concluded that the majority of sovereign credit risk was linked to the global factors. Caporin et al. (2013) analysed daily changes of CDS spreads of seven Eurozone countries ${ }^{5}$ and the UK from November 2008 to September 2011. They found that most of the correlations were less than 0.7 , and several were less than 0.50 . The average correlation across the eight sovereign countries was 0.502 . When making a comparison with the findings of Caporin et al. (2013) we conclude that the correlation between CDS changes for the Baltic markets is higher than that for the selected EU countries.

Estonia joined the euro area from January 2011. The final decision to accept the application of Estonia to join the euro area was made by European authorities in June 2010. Therefore, we divided the initial period into two sub periods from September 2008 to June 2010 and from June 2010 to February 2014. Correlation coefficients of the monthly changes of CDS spreads are presented in Tables $2 \mathrm{~b}$ and $2 \mathrm{c}$. We established that after the middle of 2010 the correlation of Estonian CDS spreads and CDS spreads of the other Baltic countries dropped down. The above supports the hypothesis that joining the euro area has some influence on the sovereign credit risk as expressed in terms of CDS.

After having observed a very high correlation of CDS spread changes between the Baltic countries, we calculated the pairwise correlation of local equity returns expressed in euros for each of the markets. The results are presented in Table 3. The local equity correlation observed across the countries is equal to 0.701 on the average. The finding we have made is that correlations with respect to equity returns are lower than those for the changes of CDS spreads. Based on the above we can conclude that interdependence between CDS spreads is higher than that between equities.

Table 3. Correlation coefficients between local equity monthly returns of the Baltic countries from October 2008 to December 2013

\begin{tabular}{|c|c|c|c|}
\hline & EE & LT & LV \\
\hline EE & 1 & 0.850 & 0.616 \\
\hline LT & 0.850 & 1 & 0.639 \\
\hline LV & 0.616 & 0.639 & 1 \\
\hline
\end{tabular}

Note: All coefficients are significant at 1 percent level.

\footnotetext{
4 The authors analysed 26 countries from 2000 to 2010.

5 France, Germany, Greece, Ireland, Italy, Portugal, Spain.
}

Our next step was to study commonality in sovereign credit spreads by using a principal component analysis. We conducted a PC analysis of the changes in sovereign CDS spreads and contrasted the results with those for equity index returns for the same countries. We used correlation matrixes in estimating the principal components. The results show that there is a strong commonality in the behaviour of sovereign CDS spread changes. In particular, the first PC explains 92.1 percent of the sovereign CDS spreads changes. In contrast, the first principal component of equity index returns for these same countries explains 80.3 percent of the variation in equity returns.

We computed a time series for the first PC of CDS changes. A correlation of this first PC index with the EURO STOXX 50 index returns is -0.732 and a correlation with changes in the VIX index is 0.514 . Moreover, a correlation between stock market returns and changes in the VIX index is -0.669 . Noteworthy, CDS spread changes are negatively correlated with the stock market return and positively correlated with changes of the VIX index. The principal source of variation across sovereign credit spreads is highly correlated with the euro stock market as measured by the EURO STOXX 50 index returns and with the VIX index. Relationships between CDS spread changes and market indexes have been investigated by a number of authors. Pan and Singleton (2008) found a strong relation between sovereign credit spreads and the VIX index, whereas Longstaff et al. (2011) found sovereign credit spreads to be significantly related to the U.S. market returns and the VIX index.

\section{Drivers of CDS spreads of the Baltic countries}

Our previous calculations show that interrelations between CDS spread changes of the countries are very high. In this part we present an analysis of dependence of CDS spread changes on market variables and macroeconomic variables for the individual Baltic country. We applied a regression analysis for each Baltic country. We selected regressors from the following two sets of variables: variables describing the domestic market and variables from the global market. In the beginning, we selected variables representing the domestic market: GDP growth rate, Debt to GDP ratio, Current Account and Local Equity return. The global variables were the following: the Dow Jones Industrial Index return representing the USA equity market, the Dow Jones EURO STOXX 50 index return which represents the euro stock market, the Chicago Board Options Exchange Volatility Index VIX and Funding cost.

Furthermore, we decided to exclude the Dow Jones Industrial index from the set of variables, because a correlation of the index with the Dow Jones EURO STOXX 50 index was very high. Finally, we had 7 variables for the regression equation: 
1. GDP growth rate $(\triangle G D P)$;

We treated the GDP growth rate as one of the main economic variables describing the health of the economy. Technically, we considered a quarterly GDP growth rate and interpolated data by using a cubic spline to obtain monthly figures.

2. Difference of the Debt to GDP ratio $(\triangle D E B T / G D P)$; We considered a quarterly ratio of the debt to GDP changes and interpolated data by using a cubic spline to obtain monthly figures.

3. Difference of the Current Account $(\triangle C A)$;

We considered a quarterly Current Account changes and interpolated data by using a cubic spline to obtain monthly figures.

4. Monthly local equities return $(L R)$ of the countries; We calculated the monthly return of the local equity index from the daily data of closing prices.

5. Monthly return of the Dow Jones EURO STOXX 50 index (ER);

We calculated the monthly return of the euro equity index from the daily data of closing prices.

6. Monthly changes of the Chicago Board Options Exchange Volatility Index ( $\triangle V I X)$;

We used the value of the index at the end of the month. The index was calculated in US dollars.

7. Monthly changes of the funding cost $(\triangle F U N)$.

We used the IMF's, 2013 approach to define the funding cost. In our calculations, the funding cost was a difference between 3-months' Euro Libor rate and EONIA. The data from the end of the month was applied.

Finally, our regression model for the monthly changes of CDS spreads $\triangle C D S_{i, t}$ obtained the following form ${ }^{6}$ :

$$
\begin{aligned}
\Delta C D S_{i, t}= & C_{i}+\alpha_{1, i} \Delta G D P_{i, t} \alpha_{1, i}+\alpha_{2, i} \Delta D E B T / G D P_{i, t}+ \\
& \alpha_{3, i} \Delta C A_{i, t}+\alpha_{4, i} L R_{i, t}+\alpha_{5, i} E R_{t}+ \\
& \alpha_{6, i} \Delta V I X_{t}+\alpha_{7, i} \Delta F U N_{t}+\varepsilon_{i, t} .
\end{aligned}
$$

There, index $i=1,2,3$ represents the country and $t$ is time.

Results of the regression analysis are presented in Table 4 . As we see from Table 4, the euro equity return is significant for CDS spread changes for all the Baltic countries at $1 \%$ level. The local equity return is significant for Lithuania and Latvia at 1\% and 5\% level respectively. As we see from Table 4, the global and local market indices have significant impact on the changes of CDS for the Baltic countries. The funding cost is significant for Latvia at 5\% level. The VIX is significant for Estonia at 10\% level.

\footnotetext{
6 We use Feasible Generalised Least Squares (FGLS) Estimation because the assumption of the homoscedasticity is violated.
}

Table 4. Results of regression analysis

\begin{tabular}{|l|c|c|c|c|c|c|}
\hline & EE & EE & LT & LT & LV & LV \\
\hline & t value & $\operatorname{Pr}>|\mathrm{t}|$ & $\mathrm{t}$ value & $\operatorname{Pr}>|\mathrm{t}|$ & $\mathrm{t}$ value & $\operatorname{Pr}>|\mathrm{t}|$ \\
\hline$\Delta$ CA & -1.752 & 0.085 & -0.070 & 0.944 & -1.009 & 0.317 \\
\hline $\begin{array}{l}\Delta \text { DEBT/ } \\
\text { GDP }\end{array}$ & $0.793^{*}$ & 0.431 & 0.598 & 0.552 & $1.762^{*}$ & 0.084 \\
\hline$\Delta$ GDP & -1.468 & 0.148 & 0.099 & 0.921 & $1.704^{*}$ & 0.094 \\
\hline LR & -0.721 & 0.474 & $-4.207^{* * *}$ & $<0.01$ & $-2.164^{* *}$ & 0.035 \\
\hline ER & $-4.084^{* * *}$ & $<0.01$ & $-4.862^{* * *}$ & $<0.01$ & $-3.206^{* *}$ & $<0.01$ \\
\hline$\Delta$ FUN & 0.120 & 0.905 & -0.743 & 0.461 & $2.389^{* *}$ & 0.020 \\
\hline \begin{tabular}{l}
$\Delta$ VIX \\
\hline $1.949^{*}$
\end{tabular} & 0.056 & -0.360 & 0.721 & 0.313 & 0.755 \\
\hline $\begin{array}{l}\text { Adjusted } \\
\text { R-squa- } \\
\text { red }\end{array}$ & 0.402 & & 0.625 & & 0.485 & \\
\hline
\end{tabular}

Note: ${ }^{*}$ - Significant at 10 percent level. ${ }^{* *}$ - Significant at 5 per-

cent level. ${ }^{* *}$ - Significant at 1 percent level.

Currently, the Debt to GDP ratio deserves exclusive attention in the $\mathrm{EU}$, because the ratio has been increasing dramatically during the period of our interest. We had a hypothesis that this ratio should have had significant influence on the country's risk. Calculations revealed that the hypothesis was misguided. Our calculations showed that this parameter was significant only for Latvia at $10 \%$. For other Baltic countries, the change of the Debt to GDP ratio was an insignificant variable. This can be explained by the fact that the Baltic countries have relatively low debt to GDP ratios. The Debt to GDP ratio of the Baltic countries did not exceed 42 percent of GDP, which is low compared to the average in the EU which is equal to 87 percent $^{7}$. The GDP growth rate was significant only to Latvia at the $10 \%$ level.

Hilscher and Nosbusch (2010) established that volatility of terms of trade in particular had a statistically and economically significant effect on credit spreads for emerging countries. Taking into account their findings, we included the current account variable into the regression. We expected that this variable would be significant in our regression. Unfortunately, this hypothesis was misleading with respect to the Baltic countries. The current account variable was not significant in our regression equation for Latvia and Lithuania. The current account was significant for Estonia at 10\% level.

It is well known that financial markets are looking ahead. The reaction of financial markets is mostly based on the expected future behaviour. Heinz and Sun (2014) considered a regression equation for the sovereign CDS where macro-economic data were replaced by the forecasting consensus of these data. We modified their approach by using macro-economic data of the Baltic countries one and two months ahead instead of the forecasting consensus in

\footnotetext{
7 The data in the end of 2013.
} 
our regression equation. Our approximation is not suitable in forecasting models, but it makes sense in finding relationship between the variables. The results are presented in Table 5 and Table 6. Our finding was that a 2-month future GDP growth rate was significant for Lithuania at $1 \%$ level.

In concluding the results of the regression analysis of CDS spreads of the Baltic countries we can stress that global and local financial indicators are the main drivers of the changes.

\section{Transmission of CDS spread changes of the Baltic countries}

The next step in our analysis focuses on the relationship between the Baltic countries. First of all we are going to analyse the relation of CDS changes of the Baltic countries and the Nordic countries - Denmark, Finland and Sweden. CDS spreads of the Nordic EU countries are presented in Figure 5.

We calculated pairwise correlation coefficients of CDS changes of the Baltic Sea region countries. The results are presented in Table 7. Sweden is the Nordic country having

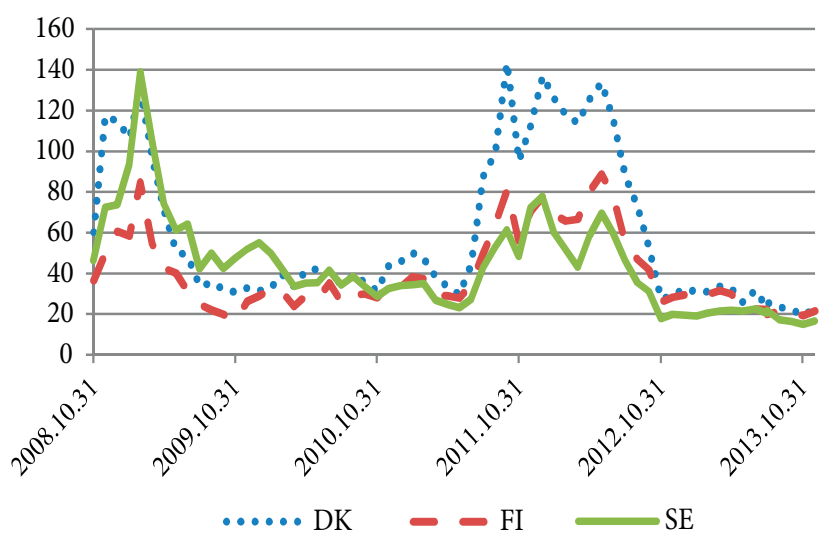

Fig. 5. CDS spreads of the Nordic EU countries in bps from September 2008 to December 2013 (source: Bloomberg)

the highest correlation with the Baltic countries. The averages of the correlation coefficients of Denmark, Finland and Sweden with the Baltic countries are equal to 0.669, 0.649 and 0.825 respectively. The results are in line with Hegerty (2012) who showed the interrelation of the currency markets of the countries. It is important to notice that the

Table 5. Results of regression analysis with macro-economic variables one month ahead

\begin{tabular}{|l|c|c|c|c|c|c|}
\hline & EE & EE & LT & LT & LV & LV \\
\hline & $\mathrm{t}$ value & $\operatorname{Pr}>|\mathrm{t}|$ & $\mathrm{t}$ value & $\operatorname{Pr}>|\mathrm{t}|$ & $\mathrm{t}$ value & $\operatorname{Pr}>|\mathrm{t}|$ \\
\hline$\Delta \mathrm{CA}$ & -1.158 & 0.252 & -0.094 & 0.926 & -0.665 & 0.509 \\
\hline$\Delta$ DEBT/GDP & 1.104 & 0.275 & 1.188 & 0.240 & 0.850 & 0.399 \\
\hline LRDP & -1.244 & 0.219 & $-1.887^{*}$ & 0.065 & 1.554 & 0.126 \\
\hline ER & $-1.802^{*}$ & 0.077 & $-3.296^{* *}$ & $<0.01$ & $-2.100^{* *}$ & 0.040 \\
\hline$\Delta$ FUN & $-3.231^{* *}$ & $<0.01$ & $-4.129^{* * *}$ & $<0.01$ & $-3.415^{* * *}$ & $<0.01$ \\
\hline$\Delta$ VIX & 0.721 & 0.474 & -0.622 & 0.536 & $1.698^{*}$ & 0.095 \\
\hline Adjusted R-squared & $2.071^{* *}$ & 0.043 & 0.731 & 0.468 & -0.233 & 0.817 \\
\hline
\end{tabular}

Note: ${ }^{*}$ - Significant at 10 percent level. ${ }^{* *}$ - Significant at 5 percent level. ${ }^{* *}-$ Significant at 1 percent level.

Table 6. Results of regression analysis with macro-economic variables two months ahead

\begin{tabular}{|l|c|c|c|c|c|c|}
\hline & EE & EE & LT & LT & LV & LV \\
\hline & t value & $\operatorname{Pr}>|\mathrm{t}|$ & $\mathrm{t}$ value & $\operatorname{Pr}>|\mathrm{t}|$ & $\mathrm{t}$ value & $\operatorname{Pr}>|\mathrm{t}|$ \\
\hline$\Delta \mathrm{CA}$ & -1.065 & 0.292 & -0.316 & 0.754 & -0.301 & 0.764 \\
\hline$\Delta$ DEBT/GDP & 0.677 & 0.502 & 1.563 & 0.124 & 0.596 & 0.554 \\
\hline$\Delta$ GDP & 0.773 & 0.443 & $-2.872^{* * *}$ & $<0.01$ & 0.229 & 0.820 \\
\hline LR & -1.073 & 0.288 & $-3.125^{* * *}$ & $<0.01$ & -1.151 & 0.255 \\
\hline ER & $-3.754^{* * *}$ & $<0.01$ & $-4.951^{* * *}$ & $<0.01$ & $-4.997^{* * *}$ & $<0.01$ \\
\hline$\Delta$ FUN & -0.301 & 0.765 & 0.501 & 0.619 & 1.337 & 0.187 \\
\hline$\Delta$ VIX & 0.807 & 0.424 & 1.047 & 0.300 & -0.481 & 0.633 \\
\hline Adjusted R-squared & 0.322 & & 0.761 & & 0.576 & \\
\hline
\end{tabular}

Notes: ${ }^{*}$ - Significant at 10 percent level. ${ }^{* *}$ - Significant at 5 percent level. ${ }^{* *}$ - Significant at 1 percent level.

Tables 4, 5, 6 reports heteroskedasticity-corrected $t$-statistics for the indicated regression explanatory variables calculated using Feasible Generalized Least Squares procedure (Ramanathan 2002). 
above coincides with a market share of Swedish banks in the Baltic countries. The data of the banking associations of the Baltic countries LBA (2014), Bankasoc (2014), EBA (2014) shows that two Swedish banks - SEB and Swedbank - have the shares of 56 percent of Lithuanian (September 2013), 61 percent of Estonian (December 2013) and 32 percent of Latvian (December 2013) banking sectors. The above illustrates that financial sectors of the Baltic countries are closely linked to Swedish banks. The high correlation of the sovereign CDS spreads of Sweden and the Baltic countries shows that financial sector is a very important transmission channel for the spillover of sovereign risk.

Our next step was to find the impact of CDS changes in one country to the changes of CDS in another. For this exercise we use the Granger casualty test. In order to produce a more sensitive analysis, we use weekly data instead of monthly data which we have used before. Table 8 presents results of Phillips-Perron Unit Root Test on CDS changes of the Baltic countries. Moreover, it provides summary statistics for each variable used in our analysis. Since the above variables are shown to be stationary, we enter them into our VAR model. After choosing the VAR (2) by minimizing the Schwarz Bayesian criterion (SBC), we analysed connections among the variables of CDS changes of the Baltic countries by using the Granger causality test. As shown in Table 9, the test statistics are significant at $1 \%$ level, except for the case of Lithuania. Thus, it seems that the past values of CDS changes in one Baltic country helps to predict CDS changes in another Baltic country, yet it is worth noticing that CDS changes in Estonia and Latvia are less helpful to predict CDS changes in Lithuania.

\section{Conclusions}

The size of the sovereign CDS market of the Baltic countries has been quite stable over the last years and the ratio of the notional amount of CDS to sovereign debt is higher than the average ratio of the sovereign CDS to the debt worldwide.

Credit risk of the Baltic countries, expressed in terms of CDS spreads, is not an individual one. In general, CDS spreads move together for all the countries. The first PC explains 92 percent of CDS changes. The global environment plays a crucial role in changes of CDS spreads of the Baltic countries. A correlation of this first PC with the EURO STOXX 50 index returns is 73 percent. Commonality in CDS spreads of the Baltic market is higher than that of the local stock market indices. The first PC of equity market explains 83 percent of variations.

Global equity market return has a significant impact on CDS spreads of all the countries. When eliminating evident influence of the global equity return, the implied volatility index VIX, the interest rate and the countries' macro
Table 7. Correlation coefficients between monthly changes of CDS spreads from October 2008 to December 2013 of the Baltic and Nordic countries

\begin{tabular}{|c|c|c|c|c|c|c|}
\hline & EE & LT & LV & DK & FI & SE \\
\hline EE & 1.000 & 0.870 & 0.836 & 0.623 & 0.597 & 0.815 \\
\hline LT & 0.870 & 1.000 & 0.870 & 0.703 & 0.699 & 0.856 \\
\hline LV & 0.836 & 0.870 & 1.000 & 0.681 & 0.650 & 0.804 \\
\hline DK & 0.623 & 0.703 & 0.681 & 1.000 & 0.856 & 0.772 \\
\hline FI & 0.597 & 0.699 & 0.650 & 0.856 & 1.000 & 0.824 \\
\hline SE & 0.815 & 0.856 & 0.804 & 0.772 & 0.824 & 1.000 \\
\hline
\end{tabular}

Note: All coefficients are significant at 1 percent level.

Table 8. Phillips-Perron stationarity test results and summary statistics (weekly CDS changes)

\begin{tabular}{|c|c|c|c|c|c|c|}
\hline Country & $\begin{array}{c}\text { Statistic } \\
(\mathrm{p} \text {-value })\end{array}$ & Mean & $\begin{array}{c}\text { Std. } \\
\text { Dev. }\end{array}$ & Min & Max & $\mathrm{N}$ \\
\hline Estonia & $\begin{array}{c}-14.46 \\
(<0.0001)\end{array}$ & -0.46 & 28.42 & -206.3 & 151.7 & 270 \\
\hline Latvia & $\begin{array}{c}-14.08 \\
(<0.0001)\end{array}$ & -0.67 & 44.16 & -292.5 & 225 & 276 \\
\hline $\begin{array}{c}\text { Lithua- } \\
\text { nia }\end{array}$ & $\begin{array}{c}-14.80 \\
(<0.0001)\end{array}$ & -0.24 & 31.28 & -181.7 & 145 & 275 \\
\hline
\end{tabular}

Table 9. Granger Causality Wald tests (weekly CDS changes)

\begin{tabular}{|c|c|c|c|}
\hline Country & Estonia & Latvia & Lithuania \\
\hline Excluded $)$ & $\begin{array}{c}\text { Chi-sq } \\
\text { (Prob.) }\end{array}$ & $\begin{array}{c}\text { Chi-sq } \\
(\text { Prob. })\end{array}$ & $\begin{array}{c}\text { Chi-sq } \\
(\text { Prob. })\end{array}$ \\
\hline Estonia & & $12.41(0.0020)$ & $5.34(0.0692)$ \\
\hline Latvia & $25.55(<0.0001)$ & & $4.60(0.1005)$ \\
\hline Lithuania & $15.25(0.0005)$ & $12.37(0.0021)$ & \\
\hline All & $28.74(<0.0001)$ & $15.35(0.0040)$ & $14.32(0.0063)$ \\
\hline
\end{tabular}

Note $\mathrm{N}=277 ; \mathrm{Lag}=2 . \mathrm{AIC}=17.839$ (Akaike Information Criterion).

parameters, residual common factors still persist, that have influence on commonality of the risk of the Baltic countries. The first PC of the residuals explains 79 percent of residual variations.

We have not established any significant impact of the changes of the amount of the debt to GDP on CDS spreads changes in all the Baltic countries. This phenomenon can be explained by the fact that the Baltic countries have smaller ratios of the debt to GDP than the rest of the EU and financial markets do not treat it as a risk factor. The current account position does not have any observable impact on credit risk of the countries either.

Credit risk expressed in terms of CDS spreads has many commonalities in the Baltic countries, yet after the decision of the European Commission to allow Estonia to introduce the euro the correlation of the Estonian CDS 
changes with those of the other Baltic countries has dropped significantly.

The Granger causality test shows that the past values of CDS changes in one Baltic country helps to predict CDS changes in another Baltic country. According to the Granger test, the spreads of the Estonian CDS and the Latvian CDShaveless impact on predicting changes of the Lithuanian CDS spreads.

CDS changes of Sweden have the highest correlation among the Nordic countries with the Baltic countries. This can be explained by a high volume of investments of Sweden into the financial sector of the Baltic countries.

\section{References}

Alter, A.; Beyer, A. 2013. The dynamics of spillover effects during the European sovereign debt turmoil, ECB Working paper No 1558.

Ang, A.; Longstaff, F. A. 2013. Systemic sovereign credit risk: lessons from the US and Europe, Journal of Monetary Economics 60(5): 493-510.

http://dx.doi.org/10.1016/j.jmoneco.2013.04.009

Association of Lithuanian Banks (LBA). 2014. Main indictors of Banks [online], [cited 11 June 2014]. Available from Internet: http://www.lba.lt/go.php/eng/Main_Indicators_of_Banks/360

Association of Commercial Banks of Latvia (Bankasoc). 2014. General information on banking sector [online], [cited 11 June 2014]. Available from Internet: http://www.bankasoc. lv/en/statistics/banks/Banku_statistika_www_12_2013_ ENG_eiro_ok.pdf

Badaoui, S.; Cathcart, L.; El-Jahel, L. 2013. Implied liquidity risk premium in the term structure of sovereign credit default swap and bond spreads, SSRN 2317966.

Beber, A.; Brandt, M.W.; Kavavejc, K. A. 2009. Flight-to-quality or flight-to-liquidity? Evidence from the Euro-area bond market, Review of Financial Studies 22: 925-957.

Beirne, J.; Fratzscher, M. 2013. The pricing of sovereign risk and contagion during the European sovereign debt crisis, ECB Working Paper No. 1625.

Bank for International Settlements (BIS). 2012. Statistical Release: OTC Derivatives Statistics at End-June 2012, Basel, November, 2012 [online], [cited 11 June 2014]. Available from Internet: https://www.bis.org/publ/otc_hy1311.pdf

Blanco, R.; Brennan, S.; Marsh, I. W. 2005. An empirical analysis of the dynamic relation between investment-grade bonds and credit default swaps, Journal of Finance 60: 2255-2281. http://dx.doi.org/10.1111/j.1540-6261.2005.00798.x

Caporin, M.; Pelizzon, L.; Ravazzolo, F.; Rigobon, R. 2013. Measuring sovereign contagion in Europe, NBER Working paper 18741, January 2013.

Carboni, A. 2011. The sovereign credit default swap market: price discovery, volumes and links with banks' risk premia. Banca D’Italia, Working paper 821.

Chobanov, P.; Lahiani, A.; Nenovsky, N. 2010. Money market integration and sovereign CDS spreads dynamics in the new EU states, William Davidson Institute Working Paper, No. 1002.
Claeys, P.; Vašíček, B. 2012. Measuring Sovereign Bond Spillover in Europe and the Impact of Rating News. Czech National Bank, Working Paper, No. 7/2012.

Coudert, V.; Gex, M. 2010. Credit default swap and bond markets: which leads the other?, Financial Stability Review, 14: 161-167.

DTCC. 2014. Trade information [online], [cited June 15 2014]. Available from Internet: http://www.dtcc.com/repositoryotc-data.aspx?tbid=6

Ericsson, J.; Jacobs, K.; Oviedo, R. 2009. The determinants of credit default swap premia, Journal of Financial and Quantitative Analysis 44: 109-132. http://dx.doi.org/10.1017/S0022109009090061

Estonian Banking Association (EBA). 2014. Banking information [online], [cited 11 June 2014]. Available from Internet: http:// www.pangaliit.ee/en/banking-information

European Commission. 2010. Proposal for a regulation of the European Parliament and of the Council on Short Selling and Certain Aspects of Credit Default Swaps, (September 15), COM (2010) 482 Final [online], [cited 15 September 2014]. Available from Internet: http://ec.europa.eu/internal_market/securities/short_selling_en.htm.

European Commission. 2014. Eurostat. Statistics Databases [online], [cited 11 October 2014]. Available from Internet: http://appsso.eurostat.ec.europa.eu/nui/submitViewTableAction.do

Fontana, A.; Scheicher, M. 2010. An analysis of Euro area sovereign $\mathrm{CDS}$ and their relation with government bonds. $\mathrm{ECB}$ Working Paper No. 1271.

Forte, S.; Pena, S.; Juan, I. 2009. Credit spreads: an empirical analysis on the informational content of stocks, bonds, and CDS, Journal of Banking and Finance 33: 2013-2025. http://dx.doi.org/10.1016/j.jbankfin.2009.04.015

Gorea, D.; Radev, D. 2014. The euro area sovereign debt crisis: can contagion spread from the periphery to the core?, International Review of Economics \& Finance 30: 78-100. http://dx.doi.org/10.1016/j.iref.2013.10.003

Gyntelberg, J.; Hördahl, P.; Ters, K.; Urban, J. 2013. Intraday dynamics of euro area sovereign CDS and bonds, BIS Working Papers No 423.

Hegerty, S. W. 2012. How integrated are the exchange markets of the Baltic Sea Region? An examination of market pressure and its contagion, Baltic Journal of Economics 2: 109-122. http://dx.doi.org/10.1080/1406099X.2012.10840520

Heinz, F.; Sun, Y. 2014. Sovereign CDS Spreads in Europe - The role of Global Risk version, Economic Fundamentals, Liquidity, and Spillovers, IMF Working Paper WP/14/17.

Hilscher, J.; Nosbusch, Y. 2010. Determinants of sovereign risk: macroeconomic fundamentals and the pricing of sovereign debt, Review of Finance 14(2): 235-262. http://dx.doi.org/10.1093/rof/rfq005

Hull, J.; Predescu, M.; White, A. 2004. The relationship between credit default swap spreads, bond yields, and credit rating announcements, Journal of Banking \& Finance (28): 27892811. http://dx.doi.org/10.1016/j.jbankfin.2004.06.010

IMF. 2013. Global financial stability report. International Monetary Fund, April 2013. 
Jacobs, J.; Karagozoglu, A. K.; Peluso, C. M. 2010. Measuring credit risk: CDS spreads vs. credit ratings. Office of the Comptroller of the Currency, Division of Economic and International Affairs.

Kallestrup, R.; Lando, D.; Murgoci, A. 2012. Financial sector linkages and the dynamics of bank and sovereign credit spreds, SSRN 2023635.

Komarkova, Z.; Lesanovska, J.; Komarek, L. 2013. Analysis of sovereign risk market indicators: the case of the Czech Republic, Czech Journal of Economics and Finance 63: 1-24.

Kliber, A. 2011. Sovereign CDS instruments in Central Europe-Linkages and Interdependence, Dynamic Econometric Models 11: 11-128. http://dx.doi.org/10.12775/DEM.2011.008

Kregzde, A.; Murauskas, G. 2014. Analysis of Lithuanian credit default swaps, Journal of Business Economics and Management (in press).

http://dx.doi.org/10.3846/16111699.2014.890130

Longstaff, F. A.; Pan, J.; Pedersen, L. H.; Singleton, K. J. 2011. How sovereign is sovereign credit risk?, American Economic Journal: Macroeconomics 2: 75-103. http://dx.doi.org/10.1257/mac.3.2.75

Norden, L.; Weber, M. 2009. The co-movement of credit default swap, bond and stock markets: an empirical analysis,
European Financial management 15(3): 529-562. http://dx.doi.org/10.1111/j.1468-036X.2007.00427.x

Pan, J.; Singleton, K. J. 2008. Default and recovery implicit in the term structure of sovereign CDS spreads, The Journal of Finance 63(5): 2345-2384. http://dx.doi.org/10.1111/j.1540-6261.2008.01399.x

Ramanathan, R. 2002. Introductory econometrics with applications. Parts 8-9. Harcourt College Publishers.

Remolona, E.; Michela, S.; Wu, E. 2008. The dynamic pricing of sovereign risk in emerging markets: fundamentals and risk aversion, The Journal of Fixed Income 17(4): 57-71. http://dx.doi.org/10.3905/jfi.2008.705542

Varga, L. 2009. The information content of Hungarian sovereign CDS spreads. Occasional paper. Central Bank of Hungary.

Wang, A. T.; Yao, C. 2014. Risks of Latin America sovereign debts before and after the financial crisis, Applied Economics 46(14): 1665-1676. http://dx.doi.org/10.1080/00036846.2014.881976

Zhu, H. 2006. An empirical comparison of credit spreads between the bond market and the credit default swap market, Journal of Financial Services Research (29): 211-235. http://dx.doi.org/10.1007/s10693-006-7626-x

Arvydas KREGZDE. PhD, is an Associate Professor at Vilnius University. He obtained his doctorate in the field of applied mathematics at Lomonosov University in Moscow. He holds a Master's degree in applied mathematics from Vilnius University. He has worked in the Bank of Lithuania as a Director of Market Operations Department and Deputy Governor of the bank. His academic research interest focuses on the field of mathematical modelling, mathematics of finance, financial markets and government policy.

Gediminas MURAUSKAS. PhD, is an Associate Professor at Vilnius University. He obtained his doctorate in the field of applied mathematics at V.M. Glushkov Institute of Cybernetics of the Ukrainian Academy of Sciences. He holds a Master's degree in applied mathematics from Vilnius University. He is co-author of a textbook, Statistics and its Applications (in Lithuanian). His recent research interests include: generalized linear mixed models, data mining. 